DOE/ID-10742 (2001)

February 2002

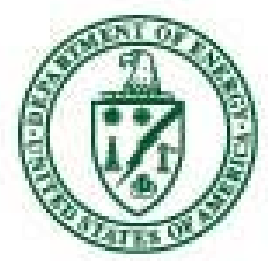

U.S. Department of Energy Idaho Operations Office

\title{
Annual Radiological Environmental Monitoring Program Report for the Fort St. Vrain Independent Spent Fuel Storage Installation
}




\title{
Annual Radiological Environmental Monitoring Program Report for the Fort St. Vrain Independent Spent Fuel Storage Installation
}

\author{
J. R. Newkirk \\ F. J. Borst, CHP \\ G. G. Hall, CHP REM
}

Published February 2002

Idaho National Engineering and Environmental Laboratory Idaho Nuclear Technology and Engineering Center Idaho Falls, Idaho 83415

Prepared for the U. S. Department of Energy Assistant Secretary for Environmental Management Under DOE Idaho Operations Office

Contract DE-AC07-99ID13727 


\begin{abstract}
This report presents the results of the 2001 Radiological Environmental Monitoring Program conducted in accordance with 10 CFR 72.44 for the Fort St. Vrain Independent Spent Fuel Storage Installation. A description of the facility and the monitoring program is provided. The results of monitoring the predominant radiation exposure pathway, direct and scattered radiation exposure, indicate the facility operation has not contributed to any increase in the estimated maximum potential dose commitment to the general public.
\end{abstract}




\section{SUMMARY}

The purpose of this report is to present the results of the Radiological Environmental Monitoring Program (REMP) conducted during 2001 for the Fort St. Vrain (FSV) Independent Spent Fuel Storage Installation (ISFSI). The results of the thermoluminescent dosimetry network did not indicate an increase in radiation levels above post-loading ambient background attributed to the facility operation. The monitoring program results support the conclusion reached in the Safety Analysis Report that operation of the facility will not result in a significant dose commitment greater than $0.15 \mathrm{mrem} / \mathrm{y}$ to the nearest resident. 


\section{CONTENTS}

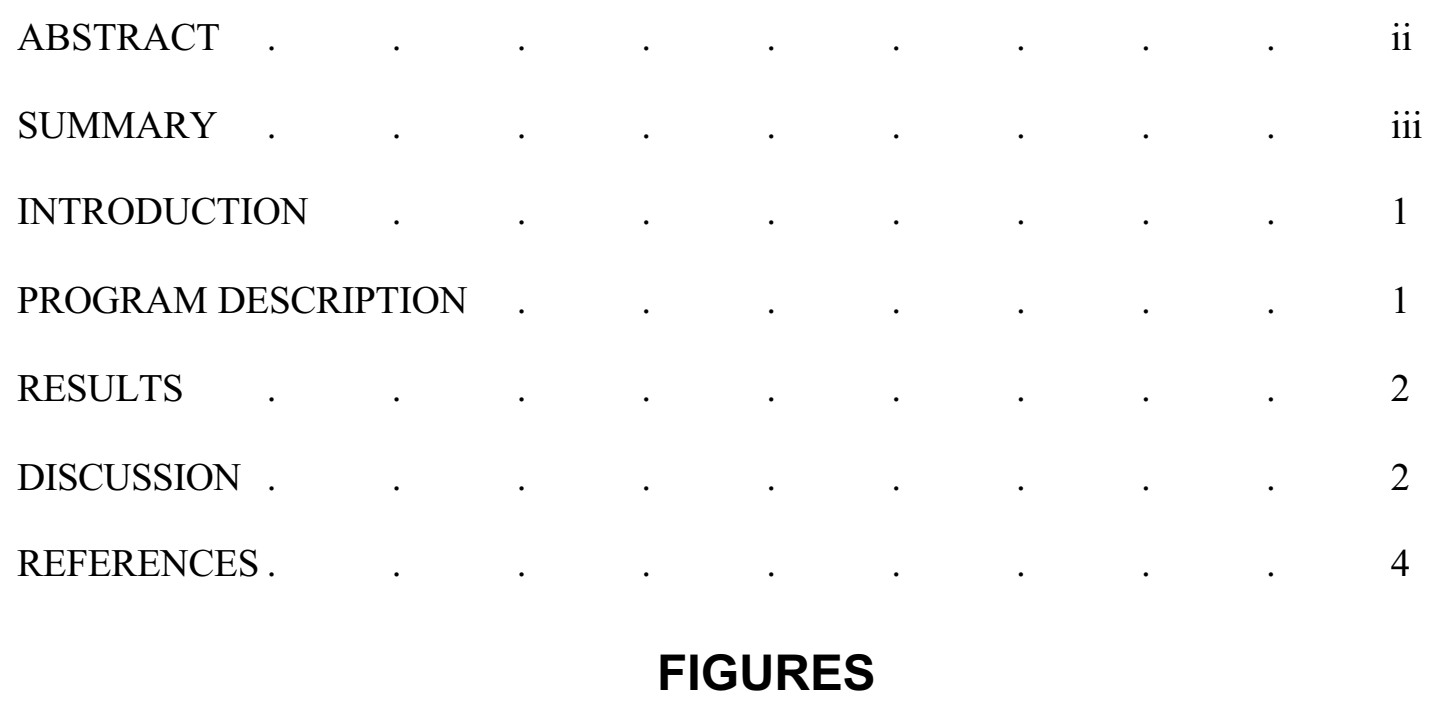

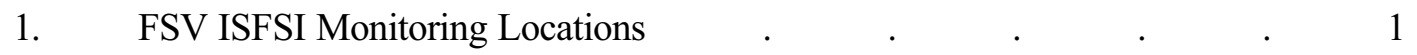

\section{TABLES}

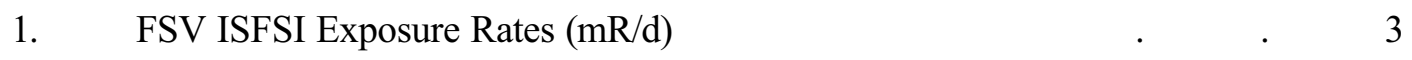

2. FSV ISFSI Airborne Tritium Monitoring Results $(\mathrm{uCi} / \mathrm{cc}) \quad$. . 3

3. Radioanalytical Intercomparison Results for June and December $2001(\mathrm{~Bq} / \mathrm{L}) \quad 4$ 


\section{Annual Radiological Environmental Monitoring Program Report for the Fort St. Vrain Independent Spent Fuel Storage Installation}

\section{INTRODUCTION}

The Fort St. Vrain (FSV) Independent Spent Fuel Storage Installation (ISFSI) is a spent fuel dry storage facility located in Platteville, Colorado. The FSV ISFSI is operated by Bechtel BWXT Idaho, LLC for the Department of Energy (DOE). The FSV ISFSI is licensed (SNM-2504) by the Nuclear Regulatory Commission (NRC) pursuant to 10 CFR 72 for authorization to store spent nuclear fuel from the Fort St. Vrain Nuclear Station. ${ }^{1}$ Spent fuel from the FSV reactor was transferred to the FSV ISFSI between December 26, 1991 and June 10, 1992. The FSV ISFSI license was transferred from the Public Service Company of Colorado (PSCo) to the U.S. Department of Energy, Idaho Operations Office (DOEID) on June 4, 1999.

A Radiological Environmental Monitoring Program (REMP) has been implemented for the FSV ISFSI in accordance with 10 CFR 72.44. This report presents the REMP results for 2001.

\section{PROGRAM DESCRIPTION}

The REMP is designed to monitor the predominant radiation exposure pathway inherent with the facility design: direct and scattered radiation. The direct and scattered radiation exposure pathway is monitored using thermoluminescent dosimetry (TLD) located along the 100 meter perimeter fence of the FSV ISFSI. Monitoring locations are identified in Figure 1.

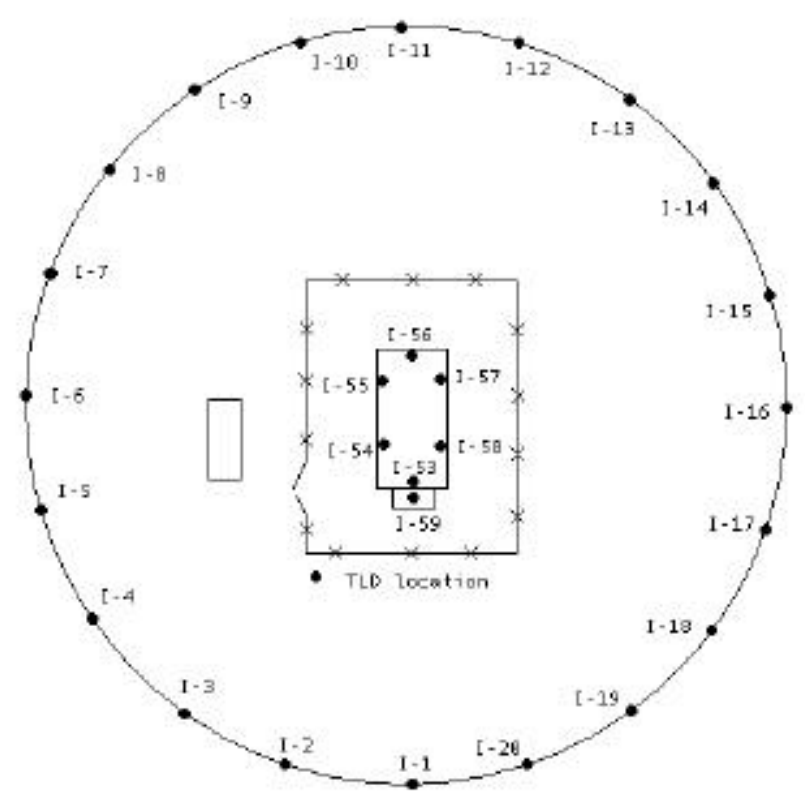

Figure 1. FSV ISFSI Monitoring Locations 
Twenty thermoluminescent dosimeters (TLD's) are located around the 100 meter perimeter fence to monitor direct and scattered radiation from the FSV ISFSI. One third of the TLD's are changed out and processed each month. An additional seven TLD's are located inside the FSV ISFSI above the charge face and in the alarm station, but are not considered part of the REMP.

Although not considered part of the REMP, molesieve samples are collected periodically within the ISFSI chimney and charge face and are subsequently analyzed for tritium radioactivity.

The FSV ISFSI facility design includes a vault drain system to capture any liquid in the facility. Although not considered part of the REMP, the vault drain is checked for liquid on a quarterly basis, and sampled accordingly if liquid is present.

\section{RESULTS}

TLD results for the FSV ISFSI are presented in Table 1 in units of $\mathrm{mR} / \mathrm{d}$. Dosimetry processing services were provided by the Idaho National Engineering and Environmental Laboratory (INEEL). The mean daily exposure rate of $0.38+/-0.04 \mathrm{mR} / \mathrm{d}$ measured at the ISFSI perimeter fence is not significantly different than the five-year historical operation mean of $0.39+/-0.05 \mathrm{mR} / \mathrm{d}$ last reported by Colorado State University (CSU). ${ }^{2}$ The mean exposure rate of $0.38+/-0.05 \mathrm{mR} / \mathrm{d}$ measured inside the charge face and alarm station is not significantly different than the four-year historical operation mean of $0.40+/-$ $0.06 \mathrm{mR} / \mathrm{d}$ for the charge face last reported by CSU. ${ }^{2}$ Previous annual REMP reports (preceding 1999) have indicated that the historical operation mean exposure rates were not significantly above preoperational and background levels for eastern Colorado.

Airborne tritium monitoring results of samples collected from the vault chimneys and charge face are presented in Table 2. There was no detected tritium.

Liquid was observed in the vault drain system during July and October 2001. Radioanalytical results from the INEEL indicated the October sample contained tritium at a concentration of $461+/-137$ pCi/L. The Minimum Detectable Activity (MDA) during the analysis was $434 \mathrm{pCi} / \mathrm{L}$.

\section{DISCUSSION}

The FSV ISFSI REMP was successfully implemented during 2001. There was no loss of radiological monitoring data. There were no sampling location changes. There were no deviations from the established sampling schedule.

The radiation dosimetry results indicate there has been no measurable increase in ambient background radiation levels outside the FSV ISFSI perimeter fence attributed to storage of the FSV fuel.

The design of the FSV ISFSI is such that in normal operation, there are no sources of radioactive material that may become airborne. Since potential airborne release pathways are not normally sampled as part of the REMP, there were no reported radionuclides released to the environment in airborne effluents in 2001. The results of the vault chimney and charge face sampling program also indicate there was no detectable release of tritium during 2001. 
Table 1. FSV ISFSI Exposure Rates (mR/d)

\begin{tabular}{|c|c|c|c|c|c|c|c|c|c|c|c|c|c|}
\hline Location & JAN & FEB & MAR & APR & MAY & JUN & JUL & AUG & SEP & OCT & NOV & DEC & Mean \\
\hline I-1 & 0.48 & - & - & 0.36 & - & - & 0.38 & -1 & - & 0.41 & - & - & 0.41 \\
\hline $\mathrm{I}-2$ & - & 0.42 & - & - & 0.38 & - & - & 0.37 & - & - & 0.44 & - & 0.40 \\
\hline I-3 & - & - & 0.41 & - & - & 0.40 & - & - & 0.36 & - & - & 0.30 & 0.37 \\
\hline I-4 & 0.45 & - & - & 0.39 & - & - & 0.40 & - & - & 0.39 & - & - & 0.41 \\
\hline I -5 & - & 0.41 & - & - & 0.39 & - & - & 0.35 & - & - & 0.38 & - & 0.38 \\
\hline I-6 & - & - & 0.40 & - & - & 0.39 & - & - & 0.36 & - & - & 0.29 & 0.36 \\
\hline I-7 & 0.41 & - & - & 0.37 & - & - & 0.37 & - & - & 0.36 & - & - & 0.38 \\
\hline I-8 & - & 0.40 & - & - & 0.38 & - & - & 0.36 & - & - & 0.37 & - & 0.38 \\
\hline I-9 & - & - & 0.40 & - & - & 0.38 & - & - & 0.39 & - & - & 0.29 & 0.37 \\
\hline I-10 & 0.40 & - & - & 0.35 & - & - & 0.40 & - & - & 0.41 & - & - & 0.39 \\
\hline I-11 & - & 0.41 & - & - & 0.38 & - & - & 0.36 & - & - & 0.39 & - & 0.39 \\
\hline $\mathrm{I}-12$ & - & - & 0.41 & - & - & 0.39 & - & - & 0.33 & - & - & 0.30 & 0.36 \\
\hline $\mathrm{I}-13$ & 0.42 & - & - & 0.35 & - & - & 0.37 & - & - & 0.39 & - & - & 0.38 \\
\hline $\mathrm{I}-14$ & - & 0.40 & - & - & 0.38 & - & - & 0.38 & - & - & 0.41 & - & 0.39 \\
\hline I-15 & - & - & 0.41 & - & - & 0.38 & - & - & 0.33 & - & - & 0.31 & 0.36 \\
\hline I-16 & 0.41 & - & - & 0.38 & - & - & 0.40 & - & - & 0.41 & - & - & 0.40 \\
\hline I-17 & - & 0.40 & - & - & 0.37 & - & - & 0.37 & - & - & 0.38 & - & 0.38 \\
\hline I-18 & - & - & 0.40 & - & - & 0.43 & - & - & 0.35 & - & - & 0.28 & 0.37 \\
\hline I-19 & 0.45 & - & - & 0.40 & - & - & 0.41 & - & - & 0.41 & - & - & 0.42 \\
\hline $\mathrm{I}-20$ & - & 0.42 & - & - & 0.38 & - & - & 0.38 & - & - & 0.37 & - & 0.39 \\
\hline Mean & 0.43 & 0.41 & 0.41 & 0.37 & 0.38 & 0.40 & 0.39 & 0.37 & 0.35 & 0.40 & 0.39 & 0.30 & 0.38 \\
\hline $\mathrm{I}-53$ & - & 0.48 & - & - & 0.44 & - & - & 0.39 & - & - & 0.42 & - & 0.43 \\
\hline I-54 & - & - & 0.38 & - & - & 0.37 & - & - & 0.33 & - & - & 0.26 & 0.33 \\
\hline I-55 & 0.35 & - & - & 0.34 & - & - & 0.35 & - & - & 0.35 & - & - & 0.35 \\
\hline I-56 & - & 0.47 & - & - & 0.43 & - & - & 0.39 & - & - & 0.41 & - & 0.43 \\
\hline I-57 & - & - & 0.42 & - & - & 0.39 & - & - & 0.35 & - & - & 0.28 & 0.36 \\
\hline I-58 & 0.40 & - & - & 0.35 & - & - & 0.37 & - & - & 0.36 & - & - & 0.37 \\
\hline I-59 & 0.42 & - & - & 0.35 & - & - & 0.36 & - & - & 0.36 & - & - & 0.40 \\
\hline Mean & 0.39 & 0.48 & 0.40 & 0.35 & 0.44 & 0.38 & 0.36 & 0.39 & 0.34 & 0.36 & 0.42 & 0.27 & 0.38 \\
\hline
\end{tabular}

Table 2. FSV ISFSI Airborne Tritium Monitoring Results (uCi/cc).

\begin{tabular}{lcccc}
\hline Location & February & May & August & November \\
& & & & \\
\hline & & & & \\
North Charge Face & $<1.53 \mathrm{E}-12$ & $<9.00 \mathrm{E}-13$ & $<1.20 \mathrm{E}-12$ & $<1.00 \mathrm{E}-12$ \\
South Charge Face & $<1.87 \mathrm{E}-12$ & $<1.41 \mathrm{E}-12$ & $<1.82 \mathrm{E}-12$ & $<9.27 \mathrm{E}-13$ \\
East Charge Face & $<9.97 \mathrm{E}-13$ & $<1.32 \mathrm{E}-12$ & $<1.72 \mathrm{E}-12$ & $<1.18 \mathrm{E}-12$ \\
West Charge Face & $<1.09 \mathrm{E}-12$ & $<8.89 \mathrm{E}-13$ & $<1.11 \mathrm{E}-12$ & $<1.29 \mathrm{E}-12$ \\
Chimney A & - & $<1.49 \mathrm{E}-12$ & - & - \\
Chimney B & - & $<8.80 \mathrm{E}-13$ & - & - \\
Chimney C & - & $<1.45 \mathrm{E}-12$ & - & - \\
Chimney D & - & $<9.38 \mathrm{E}-13$ & - & - \\
Chimney E & - & $<1.46 \mathrm{E}-12$ & - & - \\
Chimney F & - & $<.31 \mathrm{E}-13$ & & - \\
\end{tabular}


The design features of the FSV ISFSI also ensure that, during normal operation, there are no effluent streams. Although tritium was marginally detected in one vault drain sample, all of the liquid in the vault drain was collected and used for the sample analysis, therefore no radionuclides were released to the environment in liquid effluents in 2001. The presence of water in the vault drain is attributed to rainwater runoff. The detection of tritium in the rainwater runoff is attributed to both naturally occurring tritium ( 5 to $20 \mathrm{pCi} / \mathrm{L}$ ) and residual fallout from atmospheric weapons testing and reactor accidents. ${ }^{3}$

The INEEL dosimetry processor participated in the twelfth environmental dosimetry intercomparison program conducted by the DOE Environmental Measurements Laboratory (EML) during 2000, but EML has not yet published the results.

The INEEL laboratory that provides radioanalytical services for the FSV ISFSI also participated in the intercomparison program conducted by the EML. ${ }^{4,5}$ The selected intercomparison results for a liquid sample geometry are summarized in Table 3. A description of the evaluation criteria can be found at the EML website (www.eml.doe.gov). The intercomparison results during the December proficiency test are indicative of the actual analytical proficiency demonstrated during analysis of the vault drain liquid samples during the third and fourth quarters of 2001; all acceptable.

Table 3. Radioanalytical Intercomparison Results for June and December 2001 (Bq/L)

\begin{tabular}{lllll} 
Radionuclide & INEEL Value (Error) & EML Value (Error) & INEEL/EML & Evaluation \\
\hline Co-60 & $100.000(4.000)$ & $98.200(3.600)$ & 1.018 & \\
Cs-137 & $74.000(1.200)$ & $73.000(3.700)$ & 1.014 & Acceptable \\
Gross Alpha & $925.000(56.000)$ & $1900.000(190.000)$ & 0.487 & Acceptable \\
Gross Beta & $1476.000(67.000)$ & $1297.000(100.000)$ & 1.138 & Not Acceptable \\
H-3 & $101.000(10.000)$ & $79.300(2.000)$ & 1.274 & Acceptable \\
H-3 & $100.700(9.800)$ & $79.300(2.000)$ & 1.270 & Acceptable \\
& & & & Acceptable \\
Co-60 & $209.000(14.600)$ & $209.000(7.590)$ & 1.000 & Acceptable \\
Cs-137 & $46.000(3.600)$ & $45.133(2.467)$ & 1.019 & Acceptable \\
Gross Alpha & $1143.000(69.000)$ & $1150.000(115.000)$ & 0.994 & Acceptable \\
Gross Beta & $9065.000(36.000)$ & $7970.000(800.000)$ & 1.137 & Acceptable \\
H-3 & $168.000(12.000)$ & $207.000(2.690)$ & 0.812 & Acceptable*
\end{tabular}

* Acceptable with warning.

It can be concluded from the results of the FSV ISFSI REMP that direct and scattered radiation exposure from the facility during 2001 did not contribute to any increase in the maximum potential dose commitment to the nearest resident $(0.15 \mathrm{mrem} / \mathrm{y})$ projected in the FSV ISFSI Safety Analysis Report.

\section{REFERENCES}

1. 10 CFR 72, "Lic ensing Requirements for the Independent Storage of Spent Nuclear Fuel and High-Level Radioactive Waste", Code of Federal Regulations, Office of the Federal Register, August 1988. 
2. Fort St. Vrain Independent Spent Fuel Storage Installation (ISFSI) Radiological Environmental Monitoring Program (IREMP), Summary Report for the Period January 1 to December 31, 1997, Department of Radiological Health Sciences, Colorado State University, February 26, 1998.

3. Eisenbud, M. Environmental Radioactivity, Second Edition. Academic Press. 1973.

4. EML-613, "Semi-Annual Report of the Department of Energy, Office of Environmental Management, Quality Assessment Program", June 2001.

5. EML-615, "Semi-Annual Report of the Department of Energy, Office of Environmental Management, Quality Assessment Program", December 2001. 